\title{
Erratum: Genome-wide analysis reveals specificities of Cpf1 endonucleases in human cells
}

Daesik Kim, Jungeun Kim, Junho K Hur, Kyung Wook Been, Sun-heui Yoon \& Jin-Soo Kim

Nat. Biotechnol. doi:10.1038/nbt.3609; corrected online 18 July 2016

In the version of this article initially published, the year in the received date on the first page was given as "2015," but should be "2016." The error has been corrected for the print, PDF and HTML versions of this article.

\section{Erratum: No longer going to waste}

Ken Garber

Nat. Biotechnol. 34, 458-461 (2016); published online 6 May 2016; corrected after print 27 July 2016.

In the version of this article initially published, on p.460, columns 1 and 2, the number following "ACE-" was given as "2454" instead of "2494."

The errors have been corrected in the HTML and PDF versions of the article.

\section{Erratum: Nature Biotechnology's academic spinouts of 2015}

Aaron Bouchie \& Laura DeFrancesco

Nat. Biotechnol. 34, 484-492 (2016); published online 6 May 2016; corrected after print 27 July 2016.

In the version of this article initially published, on p.491, the subtitle read "double-stranded DNA" instead of "double-stranded RNA". The error has been corrected in the HTML and PDF versions of the article.

\section{Erratum: Near-optimal probabilistic RNA-seq quantification}

Nicolas L Bray, Harold Pimentel, Páll Melsted \& Lior Pachter

Nat. Biotechnol. 34, 525-527 (2016); published online 4 April 2016; corrected after print 27 July 2016

In the version of this article initially published, in the HTML version only, the equation " $\alpha_{t} N>0.01$ " was written as " $\alpha_{t N}>0.01$." In addition, in the Figure 1 legend, the formatting of the nodes was incorrect (v_1, etc., rather than $v_{1}$ ). The errors have been corrected in the HTML and PDF versions of the article. 